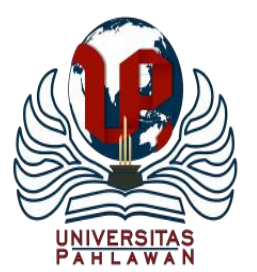

Jurnal Basicedu Volume 4 Nomor 3 Tahun 2020 Halm. 577- 585

JURNAL BASICEDU

Research \& Learning in Elementary Education

https://jbasic.org/index.php/basicedu

\title{
PENINGKATAN KEMAMPUAN BERPIKIR KRITIS DALAM PEMBELAJARAN IPA MELALUI PENDEKATAN KETERAMPILAN PROSES
}

\author{
Masani Romauli Helena Marudut ${ }^{1}$, Ishak. G. Bachtiar ${ }^{2}$, Kadir $^{3}$, Vina Iasha ${ }^{4}$ \\ Universitas Negeri Jakarta, DKI Jakarta, Indonesia ${ }^{1,2,4}$ \\ Universitas Islam Negeri Jakarta, Banten, Indonesia ${ }^{3}$ \\ E-mail : ${ }^{1}$ masaniromauli_pd15s2@mahasiswa.unj.ac.id, ${ }^{2}$ Gary.bachtiar@gmail.com, ${ }^{3}$ kadir@uinjkt.ac.id, \\ vina.iasha@gmail.com
}

\begin{abstract}
Abstrak
Penelitian ini dilaksanakan di kelas IV SDN Cawang 07 Jakarta Timur. Data dikumpulkan dengan wawancara, tes, observasi dan catatan lapangan. Penelitian ini mengggunakan rencana action research, yaitu rancangan penelitian berdaur ulang (siklus). Temuan penelitian tentang keberhasilan guru menggunakan pendekatan keterampilan proses, pada tindakan siklus 1 pertemuan pertama menunjukkan bahwa, dari 5 indikator yang direncanakan terdapat 3 indikator yang dapat dilaksanakan dengan baik, sehingga dikategorikan Kurang (K). Pada tindakan siklus 2 pertemuan kedua menunjukkan bahwa dari 5 indikator yang direncanakan terdapat 5 indikator yang dapat dilaksanakan dengan baik, sehingga dikategorikan Sangat Baik (SB). Hasil kerja siswa pada tindakan siklus 2, menunjukkan bahwa kemampuan berpikir kritis siswa siswa dalam memahami pembelajaran IPA sudah sesuai dengan yang diharapkan, sebagaimana dilihat dari hasil tes siswa dalam menyelesaikan soal yang diberikan secara tertulis memperoleh nilai rata-rata $74,6 \%$ sudah sesuai dengan kriteria keberhasilan yang telah ditetapkan yaitu $\geq 70 \%$ dengan nilai paling rendah 6,2 . Dari data hasil jawaban siswa tersebut terungkap bahwa siswa sudah mengalami peningkatan dalam kemampuan berpikir kritis dalam pelajaran IPA dengan baik.

Kata kunci: berpikir kritis, pembelajaran IPA, pendekatan keterampilan proses
\end{abstract}

\begin{abstract}
This research purposes to improve students' critical thinking skiils on science learning of grade IV students of SDN Cawang 07 Jakarta Timur through the implementation of science process learning approach. It was conducted at grade IV of SDN Cawang 07 Jakarta Timur with interview, test, observation and field note as its instruments. This is a classroom action reseacrh with cycling method. The findings showed that in cycle I, 3 indicators were accomplished and categorzed adequate and improved at 5 indicators in cycle II and categorized excellent. The students' learning outcome in cycle II proved that the science process learning approach is recommended to be implemented in the science learning process. The mean score of post test was $74.6 \%$ with minimum score was 6.2. It can be concluded that the implementation of science process learning approach was suggested to be used in science learning on Elementary level.
\end{abstract}

Keywords: Critical Thinking, Science Learning, Science Process Learning Approach

Copyright (c) 2020 Masani Romauli Helena Marudut’ Ishak. G. Bachtiar, Kadir, Vina Iasha

$\triangle$ Corresponding author :

Address : Jakarta Timur

Email : vina.iasha@gmail.com

ISSN 2580-3735 (Media Cetak)

Phone : 082113366567

ISSN 2580-1147 (Media Online)

DOI: https://doi.org/10.31004/basicedu.v4i3.401 


\section{PENDAHULUAN}

Sehubungan dengan perkembangan jaman yang semakin maju tersebut, menuntut setiap siswa untuk mampu berpikir kritis menghadapi perubahan yang terjadi. Berpikir kritis bertujuan untuk mengembangkan keterampilan dasar yang mengembangkan latihan dan aktivitas pembelajaran awal yang menarik, mengajar dengan metode pembelajaran beragam, tergantung pada situasi pendidikan aktual dan tahap pengembangan berpikir kritis (Florea, N. M., \& Hurjui, 2015). Guru hendaknya mengkaji dan memperbaiki kembali praktik-praktik pengajaran yang selama ini dilaksanakan. Menyadari pentingnya suatu sistem pembelajaran untuk mengembangkan kemampuan berpikir siswa, maka mutlak diperlukan adanya pembelajaran yang lebih banyak melibatkan siswa secara aktif dalam proses pembelajaran itu sendiri. Hal ini dapat terwujud melalui suatu bentuk sistem pembelajaran yang dirancang sedemikianrupa sehingga mencerminkan keterlibatan siswa secara aktif yang menanamkan kesadaran berpikir kritis (Massa, 2014). Siswa perlu mempersiapkan diri mereka dengan keterampilan berpikir kritis untuk menyelesaikan suatu masalah. Hasil penelitian (Florea, N. M., \& Hurjui, 2015) mengemukakan bahwa berpikir kritis didasarkan pada pembaruan pengetahuan menganalisis perbedaan dan perbandingan, yaitu pembentukan persamaan dan perbedaan, mengamati dan mengidentifikasi hubungan sebabakibat, mengekstraksi ide dan evaluasi tentang Pembelajaran IPA di SD bertujuan untuk mengajarkan individu membuat penilaian yang benar (judgment valid) dari nilai-nilai ilmu pengetahuan ilmiah dan ilmu pengetahuan yang lainnya (Fitria, 2019). Pembelajaran IPA diharapkan dapat menjadi bantuan bagi peserta didik untuk mempelajari alam sekitar dan dirinya sendiri (Laksana, 2016).

Pembelajaran IPA di SD juga bertujuan untuk memberikan ilmu pengetahuan kepada peserta didik tentang lingkungannya dan bagaimana cara bersikap, mengajarkan dan menanamkan sikap hidup ilmiah dan menerapkan metode ilmiah dalam menyelesaikan masalah, dan mengajarkan peserta didik untuk lebih mengenal dan mengetahui cara kerja serta menghargai para ilmuan penemunya (Laksana, 2016).

Berdasarkan beberapa pendapat ahli di atas dapat disimpulkan bahwa tujuan pembelajaran IPA di SD adalah agar peserta didik memahami dan mengembangkan pengetahuan konsep-konsep IPA yang saling berkaitan dengan kehidupan seharihari serta memahami lingkungan alam, lingkungan fisik, dan mampu menerapkan metode ilmiah yang sederhana dan bersikap ilmiah memecahkan masalah yang dihadapi melalui pendekatan keterampilan proses.

Kemampuan berpikir kritis siswa-siswi Indonesia masih terbilang rendah. Hal ini diketahui dari hasil Programne For International Student Assessment (PISA, 2018), skor literasi Indonesia adalah 382 dengan peringkat 64 dari 65 negara. Soal yang digunakan terdiri atas 6 level (level 1 terendah dan level 6 tertinggi). Siswa di Indonesia hanya mampu menjawab pada level 1 dan level 2 (Florea, N. M., \& Hurjui, 2015). Hal ini menunjukkan bahwa kemampuan siswa dalam menjawab soal yang mengacu pada kemampuan berpikir kritis masih sangat rendah. Proses pembelajaran yang demikian menunjukkan bahwa 
ada masalah dalam pembelajaran yang menyebabkan rendahnya berpikir kritis siswa walaupun telah banyak praktik-praktik pembelajaran yang telah digunakan selama ini namun kurang meningkatkan kemampuan berpikir kritis siswa dan proses pembelajaran yang belum optimal (Saputri, 2019).

Salah satu fakta yang terjadi dikelas IV C SDN Cawang 07 pada pelajaran IPA adalah terdapat beberapa siswa tidak memperhatikan dengan baik ketika guru sedang menyampaikan materi, artinya banyak yang siswa yang terdapat di kelas tersebut kurang antusias dan kurang fokus dalam mengikuti pelajaran. Kemudian model dan metode yang digunakan dalam pembelajaran kurang melibatkan siswa untuk berpartisipasi aktif dan interaktif selama kegiatan belajar mengajar berlangsung. Selain itu kemampuan berpikir siswa masih rendah dalam pembelajaran, dan mereka juga kurang aktif bila melakukan diskusi kelompok.

Definisi yang paling umum dari berpikir adalah berkembangnya ide dan konsep didalam diri seseorang. Ruggiero mengartikan berpikir sebagai suatu aktivitas mental untuk membantu memformulasikan atau memecahkan suatu masalah, membuat suatu keputusan, atau memenuhi hasrat keingintahuan (fulfill a desire to understand) (Izzati, 2009). Pendapat ini menegaskan bahwa ketika seseorang merumuskan suatu masalah, memecahkan masalah, ataupun ingin memahami sesuatu, maka ia melakukan suatu aktivitas berpikir.

Menurut kutipan Beyer (Wardhani, 2011) menyatakan, "Berpikir, singkatnya adalah proses mental oleh individu yang masuk akal dari pengalaman". Menurut Baron dan Stemberg menyatakan bahwa berfikir kritis merupakan suatu pikiran yang difokuskan untuk memutuskan apa yang diyakini untuk dilakukan (Rifaatul Mahmuzah, 2015).

Dalam proses pembelajaran selain untuk meningkatkan pemahaman terhadap materi yang dipelajari, perlu ditanamkan ketrampilan berpikir kritis terhadap siswa. Menyer \& Goodchild menyatakan berpikir kritis merupakan sebuah proses kognitif yang sistematis dan aktif dalam menilai argumen-argumen, menilai sebuah kenyataan, menilai kekayaan dan hubungan dua objek atau lebih serta memberikan bukti-bukti untuk menerima atau menolak sebuah pernyataan.

Menurut Pierce and associates dalam (Desmita, 2009) beberapa karakteristik yang diperlukan dalam berpikir kritis, yaitu:

1) Kemampuan untuk menarik kesimpulan dari pengamatan

2) Kemampuan untuk mengidentifikasi asumsi

3) Kemampuan untuk berpikir secara deduktif

4) Kemampuan untuk membuat interpretasi secara logis

5) Kemampuan untuk mengevaluasi argumentasi mana yang lemah dan mana yang kuat

Karakter ini harus dimunculkan dalam proses pembelajaran sedini mungkin. Akan tetapi, kemampuan berpikir kritis ini banyak ditentukan oleh manipulasi dan interaksi aktif anak dengan lingkungannya. Pengalaman-pengalaman fisik dan manipulasi lingkungan memiliki arti penting bagi terjadinya perubahan perkembangan. Sama halnya dengan interaksi sosial yang memberikan pengaruh besar dalam mengembangkan pemikiran anak 
sehingga membuat anak-anak dapat berpikir secara kritis dan logis.

Menurut Ennis terdapat dua belas indikator berpikir kritis yang dikelompokkan dalam lima kemampuan berpikir (Dina Mayadiana Suwarna, 2009) yaitu:
1. Memberikan penjelasan sederhana (elementary clarification); memfokuskan pertanyaan, menganalisis argumen pertanyaan, bertanya dan menjawab pertanyaan.

2. Membangun keterampilan dasar (basic support); apakah sumber dapat dipercaya/ tidak, mengamati dan mempertimbangkan laporan hasil operasi.

3. Membuat inferensi (inferring); mendedukasi dan mempertimbangkan hasil dedukasi, menginduksi dan mempertimbangkan hasil induksi, menentukan pertimbangan.

4. Membuat penjelasan lebih lanjut (advanced clarification); mendefinisikan istilah, mengidentifikasi asumsi-asumsi.

5. Mengatur strategi dan taktik (strategies and tactics); memutuskan suatu tindakan, berinteraksi dengan orang lain,

Menurut (Ahmad Susanto, 2013) menyatakan bahwa: "IPA adalah usaha manusia dalam memahami alam semesta melalui pengamatan yang tepat pada sasaran, serta menggunakan prosedur dan dijelaskan dengan penalaran sehingga mendapatkan suatu kesimpulan."

Menurut Haryono yang dikutip (Nur Andriani, 2015) mengungkapkan bahwa pada dasarnya mata pelajaran IPA merupakan mata pelajaran yang diharapkan sebagai sarana mengembangkan kemampuan berpikir analisis dan deduktif dengan menggunakan berbagai konsep dan prinsip IPA untuk menjelaskan berbagai peristiwa alam.

Ketika guru menggunakan pendekatan pembelajaran yang efektif salah satunya yaitu pendekatan keterampilan proses dan juga ditinjau dari berpikir kritis diharapkan siswa dapat lebih memahami materi yang disampaikan oleh guru dan siswa juga lebih senang terhadap mata pelajaran IPA, serta siswa pastinya akan lebih aktif dikelas dan akhirnya mendapatkan nilai mata pelajaran IPA yang maksimal.

Keterampilan proses sains merupakan keterampilan yang biasa dilakukan ilmuwan untuk memperoleh pengetahuan. Padilla dalam Keil, mendefinisikan bahwa keterampilan proses sains sebagai kemampuan yang dapat ditransfer secara tepat untuk beberapa disiplin ilmu, dan merefleksi dari para ilmuwan. Dia juga menegaskan bahwa keterampilan proses sains mencakup keterampilan yang terintegrasi. Dasar proses keterampilan proses sains meliputi : mengobservasi, melakukan percobaan, mengkomunikasikan, mengklasifikasikan dan memprediksi (Keil, 2009).

Funk membagi keterampilan proses menjadi dua tingkatan, yaitu keterampilan proses tingkat dasar (basic science proses skill) dan ketrampilan proses terpadu (integrated science process skill). Ketrampilan proses tingkat dasar meliputi : observasi, klasifikasi, komunikasi, pengukuran, prediksi, dan inferensi. Sedangkan ketrampilan proses terpadu meliputi menentukan variabel, menyusun tabel data, menyusun grafik, memberi hubungan variabel, memproses data, menganalisis penyelidikan, menyusun hipotesis, menentukan 
variabel secara operasional, merencanakan penyelidikan dan melakukan eksperimen (Trianto, 2010).

Ada 7 (tujuh) jenis kemampuan yang hendak dikembangkan melalui proses pembelajaran berdasarkan pendekatan keterampilan proses, antara lain:

1) Mengamati: siswa harus mampu menggunakan alat-alat inderanya (melihat, mendengar, meraba, mencium, dan merasa) untuk mengumpulkan data/informasi yang relevan dengan kepentingan belajarnya

2) Menggolongkan/ mengklasifikasikan: siswa harus terampil mengelompokan dan mengurutkan berdasarkan warna, bentuk dan ukuran

3) Menafsirkan (menginterprestasikan): siswa harus memiliki keterampilan menafsirkan fakta, data, dan informasi, atau peristiwa

4) Meramalkan: siswa harus memiliki keterampilan menghubungkan fakta, data, dan informasi. Siswa dituntut terampil mengantisipasi dan meramalkan kegiatan atau peristiwa yang mungkin terjadi pada masa yang akan datang

5) Menerapkan: siswa mampu menerapkan konsep yang telah dipelajari dan dikuasai ke dalam situasi atau pengalaman baru

6) Merencanakan penelitian: siswa harus mampu menentukan masalah dan variabel-variabel yang akan diteliti, tujuan, dan ruang lingkup penelitian

7) Mengkomunikasikan: siswa harus mampu menyusun dan menyampaikan laporan secara sistematis dan menyampaikan perolehannya, baik proses maupun hasil belajarnya kepada siswa lain dan peminat lainnya (Oemar Hamalik, 2009)

Menurut Jean Jacques dalam tahap perkembangan masa kanak-kanak, yaitu antara umur 2 sampai 12 tahun, perkembangan pribadi anak dimulai dengan makin berkembanganya fungsi-fungsi indera anak untuk mengadakan pengamatan (Haryu Islamuddin, 2013). Maka dapat dipahami pada masa ini siswa belajar dan berkomunikasi dengan lingkungannya melalui proses pengamatan indera.

Menurut teori perkembangan kognitif Piaget, peserta didik kelas IV masuk kedalam tahap operasional konkret, dimana anak melakukan operasi dan penalaran logis menggantikan pikiran intuitif selama penalaran dapat diterapkan pada contoh dan khusus dan konkret (John W. Santrock, 2007).

Berdasarkan hal tersebut diatas maka peneliti bermaksud melakukan penelitian lebih jauh mengenai pendekatan ketrampilan proses dalam meningkatan kemampuan berpikir kritis siswa pada pelajaran IPA.

\section{METODE}

Penelitian ini dilaksanakan di SDN Cawang 07 Jakarta Timur yang beralamat di Jalan Ja'ani Nasir RT 5/ RW 11 Cawang, Kramatjati, Daerah Khusus Ibukota Jakarta 13630. Jumlah peserta didik kelas IV C sebanyak 32 siswa. Waktu penelitian dilaksanakan pada tahun ajaran $2019 / 2020$.

Metode penelitian yang digunakan dalam penelitian ini adalah action research. Pelaksanaan action research model Kemmis dan McTaggart dirancang mengikuti empat tahapan yang harus 
dilalui yaitu: (1) perencanaan, (2) pelaksanaan tindakan, (3) observasi, dan (4) refleksi. Pada action research dilaksanakan dalam beberapa siklus, dengan tahapan a) bagian persiapan, b) pelaksanaan, c) pengamatan, d) refleksi. Adapun action research ini menggunakan sumber data dari guru, peserta didik, kepala sekolah dan orang tua siswa. Selain itu, peneliti juga mengumpulkan data dari catatan lapangan, dokumentasi berupa foto-foto dan video rekaman kegiatan pembelajaran di kelas. Dokumentasi dan catatan lapangan dilakukan pada setiap siklus. Sedangkan data pendukung lainnya adalah hasil refleksi yang telah dianalisis dengan berdiskusi bersama kolaborator. Teknik pengumpulan data yangdilakukan dengan cara observasi, wawancara, catatan lapangan dan teknik tes dengan menggunakan lembar soal tes kemampuan berpikir kritis yang telah dikembangkan untuk mengetahui kemapuan berpikir kritis siswa dikelas IV SD.

\section{HASIL DAN PEMBAHASAN}

Penelitian ini dilakukan melalui 2 siklus, pada tindakan siklus 1 pertemuan pertama menunjukkan bahwa, dari 5 Indikator yang direncanakan terdapat 3 Indikator yang dapat dilaksanakan dengan baik. Sehingga siklus pertama dapat dikategorikan kurang (K). Indikator yang belum dilakukan adalah membuat inferensi dan membangun keterampilan dasar.

Aktivitas guru pada siklus 1 berpengaruh pada keberhasilan siswa dalam melakukan aktivitas belajar, serta berpengaruh pada kemampuan kritis siswa. Pada pertemuan pertama ini diharapkan siswa mampu melakukan 5 butir indikator yang telah ditetapkan dari keseluruhan subjek penelitian yakni berjumlah 32 Siswa. Penelitian menunjukkan bahwa banyaknya siswa yang dapat melaksanakan indikator pertama yaitu 20 orang, indikator kedua hanya 9 orang, indikator ketiga hanya 13.

Temuan penelitian tentang keberhasilan guru dalam meningkatkan kemampuan berpikir kritis siswa alam pelajaranIPA melalui pendekatan keterampilan proses, pada siklus 2 pertemuan pertama menunjukkan bahwa, dari 5 indikator yang direncanakan terdapat 4 indikator yang dapat dilaksanakan dengan baik. 1 butir indikator yang belum dilakukan adalah membangun keterampilan dasar.

Pada siklus 2 pertemuan kedua menunjukkan bahwa semua indikator yang direncanakan dapat dilaksanakan dengan baik, sehingga dikategorikan Sangat Baik (SB). Aktivitas guru pada tindakan 2 pertemuan pertama berpengaruh pada keberhasilan siswa dalam belajar serta berpengaruh pada tingkat kritis siswa dalam pelajaran IPA. Pada tindakan siklus 2 pertemuan pertama diharapkan siswa mampu melakukan 5 indikator yang telah ditetapkan dari keseluruhan subjek penelitian yaitu 35 siswa.

Hasil kerja siswa pada tindakan siklus 2 menunjukkan bahwa hasil belajar siswa dalam memecahkan masalah sudah sesuai dengan yag diharapkan, sebagaimana dilihat dari hasil tes siswa dalam menjawab soal yang diberikan secara tertulis memperoleh nilai rata-rata $74,6 \%$, sudah sesuai dengan kriteria keberhasilan yang telah ditetapkan yaitu $\geq 70 \%$ dengan nilai paling rendah 6,2. Dari data hsil jawaban siswa tersebut terungkap bahwa siswa sudah mampu 
memecahkan soal dengan baik sehingga kemampuan berpikir kritis siswa meningkat.

Berdasarkan data dari tindakan siklus 2 dapat disimpulkan bahwa tingkat kemampuan berpikir kritis siswa rata-rata dikategorikan baik. Hal ini dikarenakan guru sudah mampu mengimplementasikan rencana pembelajaran dengan baik. Hasil observasi dan hasil tes siswa di analisis bahwa pelaksanaan pembelajaran IPA dengan menggunakan pendekatan keterampilan proses, pelaksanaannya sudah sesuai dengan yang direncanakan, sehingga berdampak pada peningkatan kemampuan berpikir kritis siswa terhadap pelajaran IPA. Oleh karena itu, berdasarkan analisis data tersebut dapat disimpulkan bahwa hasil penelitian tindakan siklus II, dianalisis dan direfleksi bahwa:

Siswa mampu berpikir kritis dalam proses pembelajaran terutama pada penggunaan alat peraga sebagai model dalam pembelajaran dan dikaitkan langsung dengan kehidupan nyata mereka, sehingga mereka belajar dari mengalaminya langsung bukan sekedar menghafal.

Guru sudah lebih memperhatikan siswasiswa yang kurang percaya diri dalam mengajukan pertanyaan ataupun dalam menjawab soal dengan cara mendekati dan membimbing siswa saat belajar ataupun setelah pembelajaran agar kemampuan berpikir kritis mereka dapat meningkat sehingga dapat lebih meningkat pada tindakan siklus II.

Guru sudah melaksanakan keseluruhan dari rencana pembelajaran yang telah direncanakan sebelumnya dengan baik. Hasil belajar siswa dari siklus pertama ke siklus kedua mengalami peningkatan yang sangat signifikan.
Hasil penelitian yang terdiri atas aktivitas siswa dan kemampuan berpikir kritis dalam pelajaran IPA melalui dua siklus dengan menggunakan pendekatan keterampilan proses mengalami peningkatan yang signifikan.

Hasil tindakan siklus pertama belum mencapai hasil yang diharapkan, dan masih terdapat indikator-indikator pendekatan keterampilan proses yang belum dilaksanakan. Pada tahap pertama melaksanakan pembelajaran, siswa sudah dapat melaksanakan tiga indikator dari lima indikator yang terdapat dalam pendekatan keterampilan proses. Hal ini membuktikan bahwa siswa sudah memahami langkah-langkah pembelajaran yang dilaksanakan dengan menggunakan pendekatan keterampilan proses, yang pada akhirnya menghasilkan nilai kemampuan berpikir kritis yang dikategorikan baik. Keberhasilan siklus kedua mencapai kualifikasi Sangat Baik (SB) karena pada kegiatan pembelajaran yang terakhir siswa mampu melaksanakan semua indikator-indikator keterampilan proses. Hal ini menunjukkan bahwa siswa telah memahami betul langkah langkah pembelajaran pendekatan keterampilan proses. Hal ini sejalan dengan pendapat Harlen (Patta Bundu, 2006) yang mengatakan bahwa setelah memahami indikator masing-masing keterampilan proses, maka siswa dapat merancang kegiatan percoban yang dapat memberikan kesempatan siswa untuk melatih dan menunjukkan keterampilan yang diinginkan. Keberhasilan tindakan dari siklus pertama ke siklus kedua karena siswa telah memahami indikator keterampilan proses yaitu keterampilan melakukan pengamatan, keterampilan mengklasifikasi, keterampilan 
menginterpretasi data, keterampilan meramalkan atau menyimpulkan, keterampilan menerapkan, keterampilan merencanakan penelitian, dan keterampilan mengkomunikasikan hasil pengamatan maupun penelitiannya kepada orang lain baik secara lisan maupun secara tertulis.

Usman dan depdikbud (Hafid, 1996) yang menyatakan bahwa keterampilan proses sains yang diharapkan dimiliki oleh dan berkembang pada siswa diantaranya adalah keterampilan melakukan pengamatan, mengklasifikasi menginterpretasi, keterampilan meramalkan atau menyimpulkan data, keterampilan menerapkan, merencanakan penelitian, dan mengkomunikasikan hasil.

Experiments and hands-on activities can be inspiring and can help students develop a conceptual understanding of scientific ideas and transferable skills, such as critical thinking. But in order for these kinds of activities to be truly effective, school principals and teachers need to be prepared. Principals need to ensure that the laboratory material is in good shape and that teachers are supported and trained accordingly. Teachers need to design well-structured laboratory activities that make tangible key scientific concepts and ideas, and help students make the links between the hands-on activities, scientific ideas and real-life problems. Students should also be made aware that when participating in these activities, they are manipulating ideas as well as objects (PISA, 2018). Dengan demikian, pendekatan keterampilan proses melalui pembelajaran IPA dapat membantu siswa untuk mengembangkan pemahaman konseptual ilmiah dan meningkatkan kemampuan berpikir kritis siswa.

\section{KESIMPULAN}

Penggunaan pendekatan keterampilan proses dapat meningkatkan kemampuan berpikir siswa dalam pelajaran IPA kelas IV C di SDN Cawang 07 Jakarta Timur. Hal ini terbukti adanya perkembangan aktivitas belajar dari siklus pertama dengan kualifikasi Baik (B) ke siklus kedua dengan kualifikasi Sangat Baik (SB). Proses pembelajaran IPA dengan menggunakan pendekatan keterampilan proses dapat dicapai karena dari satu siklus ke siklus berikutnya terus diadakan refleksi dan perbaikan. Hasil ini dapat dicapai karena adanya kerjasama antara peneliti, pengamat, dan wali kelas IV C dalam merancang, melaksanakan, mengobservasi, dan merefleksi secara berdaur ulang selama dua siklus.

\section{REFERENSI}

Ahmad Susanto. (2013). Teori Belajar dan Pembelajaran di Sekolah Dasar. Kencana.

Desmita. (2009). Psikologi Perkembangan Peserta Didik. Rosdakarya.

Dina Mayadiana Suwarna. (2009). Suatu Alternatif Pembelajaran Untuk Meningkatkan Kemampuan Berpikir Kritis Matematika. Cakrawala Maha Karya.

Fitria, Y. (2019). Landasan Pembelajaran Sains Terintegrasi (Terpadu) untuk Level Dasar. Sukabina Press.

Florea, N. M., \& Hurjui, E. (2015). Critical thinking in elementary school children. Procedia-Social and Behavioral Sciences. 180, 565-572.

Hafid. (1996). Studi Kemampuan Guru SD Menerapkan Pendekatan Keterampilan Proses Dalam Pengajaran IPA Kelas V SD Kecamatan Sukasari Kota Madya Bandung. fakultas pendidikan Matematika dan IPA institut keguruan dan ilmu pendidikan.

Haryu Islamuddin. (2013). Psikologi Pendidikan. Pustaka Pelajar.

Izzati, N. (2009). Berpikir Kreatif dan Kemampuan Pemecahan Masalah Matematis: 
Apa, Mengapa, dan Bagaimana Mengembangkannya Pada Peserta Didik. Prosiding Seminar Nasional Matematika Dan Pendidikan Matematika, 49-60.

John W. Santrock. (2007). Perkembangan Anak. Erlangga.

Keil, H. anc Z. (2009). Improvement In Student Achivement And Science Prosocess Skills Using Environmental Health Science Problem-Based Learning Curricula. Electrical Journal Of Science Education, Vol 13, No, 4.

Laksana, D. N. L. (2016). Miskonsepsi Dalam Materi IPA Sekolah Dasar. JPI (Jurnal Pendidikan Indonesia), 5(2), 166-175.

Massa, S. (2014). The development of critical thinking in primary school: the role of teachers' beliefs. Procedia-Social and Behavioral Sciences, 141, 387-392.

Nur Andriani. (2015). Pengaruh Metode Pembelajaran Kooperatif dan Gaya Kognitif Terhadap Hasil Belajar IPA Siswa Kelas V Sekolah Dasar Negeri 147 Palembang. Jurnal Pendidikan Dasar, Volume 6 E.

Oemar Hamalik. (2009). Kurikulum dan Pembelajaran. Bumi Aksara.

Patta Bundu. (2006). Penilaian Keterampilan Proses dan Sikap Ilmiah. Depdikbud.

PISA. (2018). ASSESSMENT AND ANALYTICAL FRAMEWORK (O OECD 2019.

Rifaatul Mahmuzah. (2015). Peningkatan Kemampuan Berpikir Kritis Matematis Siswa SMP Melalui Pendekatan Problem Posing. Jurnal Peluang, Vol 4 No 1(2302-5158).

Saputri, A. C. (2019). Improving Students' Critical Thinking Skills in Cell-Metabolism Learning Using Stimulating Higher Order Thinking Skills Model. . International Journal of Instruction, 12(1), 327-342.

Trianto. (2010). Model Pembelajaran Terpadu: Konsep, Strategi, dan Implementasinya dalam Kurikulum Tingkat Satuan Pendidikan (KTSP). Bumi Aksara.

Wardhani, P. . (2011). Kemampuan Berpikir Kritis Dan Kreatif Matematika. http://furahasekai.wordpress.com/2011/10/06 /k emampuan-berpikir-kritis-dan-kreatifmatematika/, 